\title{
An investigation of television programs that illustrates superstition and its effect on viewers
}

\section{DOI: http://doi.org/10.26758/8.1.28}

\author{
Arulchelvan Sriram
}

Department of Media Sciences, Anna University, Chennai, India

Address correspondence to: Arulchelvan Sriram; E-mail: arulchelvansriram@gmail.com

\begin{abstract}
Objectives. Superstitious beliefs continue to plague the Indian society despite efforts from revolutionists and various organizations, who have used science to eradicate some beliefs. People with deep rooted superstitions face the risk of losing their families and livelihoods due to their over dependence on such beliefs. To overcome this problem, media are used to create awareness among people. This study aims to check whether non-fiction television programs on superstitions play a role in changing people's mind-sets.

Materials and Methods. Content analysis was done on non-fiction programs like Moondravathu Kan, Nambinal Nambungal and Marmam that aired during February and March 2016. Totally 40 episodes of the programs were analysed. The survey method was adopted to understand how superstitious content in Tamil television affected the audience. A purposive sampling technique was used to identify 132 respondents.

Results. Majority of the content is related to religious beliefs and blind beliefs like magic healing, future prediction and black magic. These programs are produced based on information gathered from superstitious practitioners or the public and is telecast in a dramatized form. Almost $65 \%$ of the episodes use a neutral narrative tone passing no judgments on such beliefs. The survey revealed that around half of the respondents believe in superstitions. People believe that the majority of the stories are only partially true.

Conclusion. Watching of these programs has resulted in superstitious beliefs being reinforced in few people and has stimulated interests in some people to know more about such superstitions rather than creating awareness on the negative effects. This study therefore recommends that programs focus on providing scientific explanations and having expert discussions that provide an in depth understanding of a superstition rather on simply showcasing a superstition.
\end{abstract}

Keywords: superstitions; TV programs; awareness; audiences; eradication

\section{Introduction}

Superstitions are beliefs or practices that presuppose a faulty understanding about cause and effect, usually by assuming concepts of causality that have been rejected by modern science but may represent long-standing popular beliefs or practices. Superstition simply means a belief with no scientific reason but followed by many as blind beliefs with the thought that there may be any reason behind such beliefs. Many such superstitious beliefs may be harmless but few others are physically, psychologically and economically harmful. This study is about some of the harmful beliefs like black magic, witchcraft, supernatural shown in non-fiction television shows and the audience's perception about these shows and their content. 


\subsection{Superstition}

Superstition has many definitions which differ from each other in few aspects and show similarity in few other aspects. According to Corsini (2002, p. 419), superstition is a belief or a practice based on the operation of supernatural or magical forces, such as charms, omens, and exorcism, or any unscientific belief accepted without question, groundless or unfounded notion. Alternatively, superstition is defined as an irrational belief or practice resulting from ignorance or fear of the unknown. The validity of superstitions is based on belief in the power of magic and witchcraft and in such invisible forces as spirits and demons.

Superstitions and selfish desires weave a pattern of mind which interprets objective and subjective happenings in life as forebodings of personal weal and woe. Superstitions have been in existence from stone age because people in the olden days were not aware of the science behind the uncontrollable events (Khantipalo, 2013). "The origin of certain superstitions is often connected to the intention of attributing adverse events to specific causes" (Cercignani quoted in Morris, 2013, p.39).

This idea about understanding of superstition is that inclinations towards illusion make weak men superstitious and superstitious men weak. The illusion that leads them to mistake the subjective for the objective, to take the voice of inner sense for knowledge of things themselves, also makes the tendency to superstition comprehensible.

Superstitions exist in all cultures throughout the globe and are as old as mankind. Many customs that are being followed now as a part of our culture have evolved from superstitious beliefs of the past. It is also said that superstitions of today are the scientific facts of tomorrow (Balderston, 1927).

\subsection{Superstition and Psychology}

Richard Wiseman et al. (2004) says a large body of research has attempted to develop theories about the function and origin of superstitious beliefs on the basis of the psychological correlates of such beliefs. Most of this work has measured superstitious belief using the paranormal belief scale (PBS), and tended to find that superstitious belief is associated with poor psychological adjustment such as low self-efficacy and high trait anxiety. However, the PBS refers solely to negative superstitions (e.g., breaking a mirror will cause bad luck) and omits items referring to positive superstitions (e.g., carrying a lucky charm will bring good luck). Positive superstitions may serve different psychological functions in comparison with negative superstitions.

According to Ofori et al. (2016), superstitions are behaviors that people perform in an attempt to affect or control their future. Superstitious behaviours are a way people think they can control their fate by performing certain tasks in a certain way to either help alleviate anxiety or to simply better their chances in a certain situation.

Most human behavior can be classified as a superstitious ritual. Many of very same belief are the ones change how the person feels. People try to remove needless and trivial superstitions by casting them on the basis of enlightenment and progress, but invariably they would find it harder to exclude them from altogether. Even though it acts like superficially irrational and also might seem reasonable in many cases. For them, superstitious beliefs and ritual work on the basis of psychology rather than magic (Risen and Nussbaum, 2013).

The earlier studies on supernatural and paranormal belief tend to be more dismissive towards the believers and further question their intellectual ability, educational qualification and 
even their personal belief (Emme, 1940; Lundeen and Caldwell, 1930). However, those studies heavily lean on simple superstitions, but in recent research focus on more nuanced and complex phenomena in likes of ESP, psychokinesis, and precognition (Boshier, 1973; Irwin, 1993). Many other researches have found that people who believe in paranormal phenomena especially among college and university students do not generally reject the notion of mainstream science or technology (Schouten, 1983). Also, some research concludes that in some cases people who have higher education and intellectual abilities tend to believe in paranormal phenomena (McGarry and Newberry, 1981).

The further studies shown there are significant gender gaps among the paranormal believers. Here the women believe in paranormal phenomena more their male counterparts. (Irwin, 1993; Rice, 2003). As men have prone to believe in extra-terrestrials, UFOs, alien technologies and other scientific myths (e.g. Rice, 2003). According to Blackmore (1994), males are socialized and exposed to contents associated with science-based contents. And women tend to lean towards in religious and fantasy based myths. Additionally, a study by Lester, Thinschmidt and Trautman (1987) state that precognition experience and paranormal belief were linked to feeling and intuition, and support the view that believers could be less logical.

\subsection{Superstition and Religion}

Many of the superstitions prevailing today are associated with religion. Different religions have different superstitions, which are mostly correlated with their religious culture. Burhmann and Zausg (1983) found that superstitious behaviors and practice were directly correlated with religious beliefs. Earlier studies also found that traditional religious belief correlated positively with belief such as witchcraft and precognition, but negatively with belief such as spiritualism and nonsignificantly with belief in psi, superstition, and extraordinary life forms (Tobayck and Milford, 1983). Another study found that the results differ slightly different with religiosity correlating positively with belief in psychic healing and negatively with UFO belief (Clarke, 1991).

Wuthnow (1976) also reported that belief in astrology is stronger in people who are unable to work or who are looking for a job, but, in the study by Emmons and Sobal (1981), the correlation between astrological belief and unemployment was not significant. The significant data for religion, superstitions, and astrology nevertheless are consistent with the social marginality hypothesis.

Tobacyk et al. (1988) consider that traditional religious belief may be a major exception to the general trend of a decline in number of paranormal beliefs across groups of increasing age. But Emmons and Sobal (1981) found that there are no significant age-related differences in religious belief, and other studies have actually noted an increase in religiosity among elderly.

According to Sparks and Miller (2001), there are sound conceptual reasons, by which the less relationship between superstition and religious belief domains are explained. As Sparks suggests, there are complex reasons surrounding the lack of endorsement in most paranormal phenomena when it deals with religious fundamentals This is due, in a way, to religious believers who shun the possibility of occurrence of such phenomena and secondly, to the direct religious teachings which insists that the followers have complete and unflinching faiths. These factors are untreatable using the scientific method.

\subsection{Superstitions in India}

Though we are living in the era of advanced science and technology, few old beliefs, customs, and superstitions have yet changed. There are many superstitions and blind beliefs 
predominant in India. The only remedy of these blind beliefs is considered to be education and social awareness. Most of the people are superstitious in some way without their knowledge. It is said that science alone can solve the problems of hunger and poverty, of insanitation and illiteracy, of superstition and deadening custom and tradition, of vast resources running to waste, of a rich country inhabited by starving people.

There are endless beliefs and superstitions in India which are associated with every aspect of daily life right from birth to death of a person. Few beliefs find their way into the religious texts and scriptures of India. In India, till mid-nineteenth century, many women were burnt alive in their husbands' funeral pyre because of the superstition that they would live together in heaven. Similarly, human sacrifices were carried out all over India, either to appease God or to get blessings of god. Likewise, many superstitions existed in India. These beliefs act as destruction to our knowledge and depress the basic impulse to think and act. All superstitions are unsafe since they inactivate the thinking capacity of people. Besides, they capture human attempt and activity. And also they make individuals misuse their vitality, time and cash in useless customs and rituals. These things lead to delay in the advancement of society. Thus, it is necessary for a society to be cautious about superstitions. These things collectively reduce the reasoning brain of our people and reinforce the roots of superstitions among the society.

\subsection{Superstition and Media}

Media interpretation of the superstitious beliefs and practices influence the way people think about the subject particularly the emotional effects of frightening in movies and television programs. Such films and Television serials can dramatically raise the levels of physiological arousal and induce a variety of post-viewing effects, such as haunting images, bad dreams, fear of being alone, and the fear of going into a certain room in the house (Cantor 1994; Sparks, Spirek and Hodgson 1993).

According to Gerbner et al. (2002), television cultivates a common outlook or world view among its viewers. The more television a person watches, the more likely he or she is to accept the premises and facts of television reality as if they were facts of the world of everyday reality.

Media has a role to play in removing the blind beliefs from a society especially television channels owing to their impact on audience. But there are certain television channels that force us to believe certain blind faiths. The pictures in people heads are mainly constructed from the pictures they get from mass media (Lippmann, 1922).

Among scholars and skeptics, there is a common assumption that the mass media should take a major responsibility for the fact that so many people seem to accept paranormal claims uncritically. The reason for the prevalence of "absurd beliefs" among the populaces of very culture is to be found in the uncritical acceptance and promotion of these notions by the media. Kurtz (1985) called attention to the, "dominant influence of the media in forming [paranormal] attitudes and beliefs," and charged that the media often "behave totally irresponsibly in treating 'paranormal' occurrences". Feder (1984) blamed the media for the problems faced by archaeologists in their attempts to overcome the many reports of "unverified claims". Maione (1998) wrote that the programs on major TV networks often present a misleading account of the scientific status of paranormal claims by failing to fairly present the skeptical side of the story. A program that misrepresents the evidence for a particular claim is bad, but one that misrepresents the scientific method in doing so is many times worse. These blind beliefs shown on television have greater impact on audience behavior. 
Television has great impact on psychology of the audience; the audience tends to believe most of the things which they see on television. The more television a person watches, there is more chance that the person may accept the premises and particulars of television as if they were real facts of the world. So, the superstitions shown in Non-Fiction programs can reinforce superstitious beliefs in audience, which may result in adverse reaction in audience psychological behavior and it may act as a barrier to the development of scientific knowledge in individuals. Superstition also has close relation with age, gender, geography and educational qualifications of individuals because it is found that educated youths possess less superstitious beliefs than elders. It is also found that media programs are one of the reasons for the existence of superstitions in the society.

\subsection{Superstition activities in media and Laws in India}

The News Broadcasters Association (NBA), Press Council of India and the Union Ministry of Information and Broadcasting have issued guidelines for telecasting programs and advertisements in this regard. But the television channels neglect them and continue to air such programs encouraged by the stance of the government as well as the parties. Many anti-superstition activists such as Narendra Dabholkar have criticized that television programs are promoting superstition.

Indian Ministry of Information and Broadcasting has issued an advisory to various entertainment and news channels not to engage in contents that heavily encourages in superstition and blind belief. This advisory was sent on 7th June 2013 to the media organizations such as News Broadcasters Association (NBA), the Indian Broadcasting Foundation (IBF) and the Advertising Standards Council of India. Later a copy of the note was also sent to other media organizations like Electronic Media Monitoring Centre, or EMMC, a unit of the government that monitors television and radio content. The note which was circulated among various broadcasting companies said some channels have been showing programs that encourage superstitious beliefs. The advisory also insists on miraculous solutions or cure to problems by unauthorized babas or self-proclaimed gurus or godmen should be avoided.

The Maharashtra Prevention and Eradication of Human Sacrifice and other Inhuman, Evil and Aghori Practices and Black Magic Act, 2013 is a criminal law act for the state of Maharashtra. The act criminalizes practices related to black magic, human sacrifices, use of magic remedies to cure disorder and other such acts which exploit people's superstitions. The bill has 12 clauses which criminalize the acts such as defrauding or terrorizing people in the name of miracle, Carrying out or encouraging acts which endanger life or cause grievous injury in order to gain supernatural powers, Carrying out or encouraging inhuman acts or human sacrifice in quest of some bounty or reward, Creating the impression that a person has supernatural powers and compelling people to follow his/her orders, Claiming the ability to invoke ghosts, causing panic or intimidating others by threatening to invoke ghosts, or creating the impression of possession, preventing the person from seeking medical treatment, and compelling him/her to inhuman acts, Preventing a person from seeking medical advice and compelling him/her to take magic remedies, Claiming to perform surgery by fingers (psychic surgery) and claiming to change the sex of an unborn foetus.

Although the human sacrifice is already considered murder in India, encouraging human sacrifice has been criminalized in this law. Each infraction carries a minimum sentence of six months and a maximum sentence of seven years, including a fine ranging from 5,000 to 50,000 rupees. The offenses are non-bailable and cognizable. There are only around 5 states in India that have a law against such practices. 
Programme and Advertising Codes Prescribed under the Cable Television Network Rules, 1994 Rule- 6. No program which encourages superstition or blind belief should be carried in the cable service; Superstition gives rise to various fears and anxieties that are unfounded. It holds back the achievements of many healthy and good programs. Superstitions retard the scientific knowledge of civilization. Previous studies indicate that nowadays, the Indians in particular, rather than all the Asians, are exceptionally superstitious like Europeans used to be about one thousand years ago. Even educated persons fall prey to superstitions.

\subsection{Non-Fiction Television Programs}

Non-fiction is the form of any narrative or other communicative work whose assertions are understood to be fact. Narrative non-fiction relates stories that really happened but in a way that draws the attention of audience just like fictional stories, it tells a true story but with lots of drama in it. This presentation may be accurate or not which means it can give either a true or a false account of the subject in question. However, it is generally assumed that authors of such accounts mostly believe them to be true at the time of their composition or, at least, pose them to their audience as true events. According to the authors reporting the beliefs of others in a non-fiction format is not necessarily an endorsement of the ultimate authenticity of those beliefs, it is simply like saying it is true that people believe in them. These kinds of Non-Fiction programs make use of curiosity of audience to gain popularity among people. In that way, they popularize the superstitions of one place to many others.

Similarly, every Tamil channel would have at least one Non-Fiction programs scheduled in prime hours or at weekends which would be the popular program of that channel, for example, programs like Nandanthathu Enna, Nijam, Nambinal Nambungal, and Munjenmam were all popular Non-Fiction programs of that period. Some of the superstitious beliefs which are mostly portrayed in Tamil Non-Fiction programs are supernatural beings, ghosts, religious sentiments, predictions, precognitions, and miraculous healing methods. These programs may influence the viewers and make them believe in certain practices related to superstitions, which may have a psychological and financial impact on them.

Hence, the television plays an important role in entertaining and educating people and creates an impact on audiences in terms of communication, education, behavior, etc. The Constitution of India stresses cultivating awareness about science as the responsibility of the people. This incorporates media also. A lot of previous insights from literature has also suggested that rather than telecasting such programs, it can attempt to make awareness about such people who trick the general population for their own benefit and fame. So, this study attempted in order to explain the impact of non-fiction programs in Tamil channels, which are reinforcing superstition among the general audience.

To study the above-said research problem, this research has analyzed the content of superstitious programs in Tamil Television channels as well as its impact on the audience. The three major objectives to meet in this study are:

- To identify the superstitious programs that have been broadcasted on Tamil Television channels.

- To analyze the structure and presentation of the superstition related programs on Tamil Television channels.

- To find out the impact of the superstitious content broadcasted on Television upon the audience. 


\section{Material and methods}

In this research, content analysis and survey methods were followed for data collection. The content analysis was done on selected Non-Fiction programs such as Moondravathu Kan (Vendhar TV), Nambinal Nambungal (Zee Tamil TV), Marmam (Vasanth TV), for a period of one month i.e. from $1^{\text {st }}$ February 2016 to $1^{\text {st }}$ March 2016. Totally 40 episodes of above programs were analysed during the study. The content related to superstition, documentary style, the tone of narration, and presentation style were analyzed. The defined set of parameters was drawn and the content analysis was done.

The survey method was adopted for the study to find out the influence of superstitious content of Tamil television Non-fiction shows. The survey was conducted among the audience aged between 18 to 70 years through a questionnaire. The sampling technique adopted for this study is non-probability purposive sampling. The samples who watch Non-Fiction television programs were identified and the number of samples for this study is about 132 respondents.

\section{Results}

\subsection{Results of content analysis}

The content analysis was done on selected non-fiction programs such as Moondravathu Kan (Vendhar TV), Nambinal Nambungal (Zee Tamil TV), Marmam (Vasanth TV), for a period of one month.

Table1 . Synopsis of Superstition Non-Fiction Programs

\begin{tabular}{|c|c|c|c|}
\hline $\begin{array}{c}\text { Parameters/ } \\
\text { Channels }\end{array}$ & Vendhar TV & Zee Tamil TV & Vasanth TV \\
\hline $\begin{array}{l}\text { Title of the } \\
\text { program }\end{array}$ & Moondravathu Kan & Nambinal Nambungal & Marmam \\
\hline $\begin{array}{l}\text { Duration of the } \\
\text { program }\end{array}$ & 30 minutes & 60 minutes & 30 minutes \\
\hline Time slot & $9.30 \mathrm{pm}$ to $10 \mathrm{pm}$ & $9.00 \mathrm{pm}$ to $10 \mathrm{pm}$ & $9.00 \mathrm{pm}$ to $9.30 \mathrm{pm}$ \\
\hline Day of Telecast & Monday to Friday & Sunday & Sunday \\
\hline $\begin{array}{l}\text { Genre of the } \\
\text { program }\end{array}$ & Non-fiction & Non-fiction & Non-fiction \\
\hline $\begin{array}{l}\text { Theme of } \\
\text { program }\end{array}$ & Mystery, & Thriller, Mystery, Horror & $\begin{array}{l}\text { Thriller, Mystery, } \\
\text { Horror }\end{array}$ \\
\hline $\begin{array}{l}\text { Format of } \\
\text { program }\end{array}$ & Documentary & $\begin{array}{l}\text { Documentary, } \\
\text { Docudrama }\end{array}$ & $\begin{array}{l}\text { Documentary, } \\
\text { Docudrama }\end{array}$ \\
\hline $\begin{array}{l}\text { Content of the } \\
\text { program }\end{array}$ & $\begin{array}{l}\text { Religious beliefs, } \\
\text { Supernatural beliefs, } \\
\text { Blind beliefs, } \\
\text { Precognition, } \\
\text { Paranormal beliefs. }\end{array}$ & $\begin{array}{lr}\text { Religious } & \text { beliefs, } \\
\text { Supernatural } & \text { beliefs, } \\
\text { Blind } & \text { beliefs, } \\
\text { Precognition, Paranormal } \\
\text { beliefs. }\end{array}$ & $\begin{array}{l}\text { Religious beliefs, } \\
\text { Supernatural } \\
\text { beliefs, } \\
\text { beliefs, } \\
\text { Precognition, } \\
\text { Paranormal beliefs. }\end{array}$ \\
\hline
\end{tabular}




\begin{tabular}{|l|l|l|l|}
\hline $\begin{array}{l}\text { Method of } \\
\text { collecting } \\
\text { information for } \\
\text { program }\end{array}$ & $\begin{array}{l}\text { The crew of the } \\
\text { program collects the } \\
\text { information through } \\
\text { their Facebook page } \\
\text { from the public. }\end{array}$ & $\begin{array}{l}\text { The research team of the } \\
\text { program collects } \\
\text { information and they } \\
\text { provide contact number } \\
\text { in the end of the program } \\
\text { and ask public for } \\
\text { information. }\end{array}$ & $\begin{array}{l}\text { This channel } \\
\text { gathers information } \\
\text { from news sources } \\
\text { and the details of } \\
\text { the information's } \\
\text { obtained are } \\
\text { investigated }\end{array}$ \\
\hline $\begin{array}{l}\text { Audience rate of } \\
\text { interest }\end{array}$ & $45 \%$ & $35 \%$ & $20 \%$ \\
\hline $\begin{array}{l}\text { Disclaimer } \\
\text { warning }\end{array}$ & Yes & Yes & No \\
\hline Segments & 2 & 4 & 2 \\
\hline
\end{tabular}

\subsubsection{Theme of Program}

The theme followed by the programs is a combination of mystery, suspense and horror. The program explores various elements related to myths and mysteries all over the world which makes these programs popular by grabbing the attention of people who are clueless about the mysteries of the world and the reason behind it. The programs Moondravathu Kan and Nambinal Nambungal explore myths and mysteries that are within the country, whereas Marmam explores various myths and mysteries from different parts of the world.

\subsubsection{Format of the Program}

The Non-Fiction programs Nambinal Nambungal and Marmam follow both documentary and docudrama formats of storytelling, where the story follows either observational documentary style or Participatory documentary style in which the anchor participates in lively action along with the people and investigates the details. In docudrama format, the real incident is enacted as a drama to convey the story to the audience.

\section{Figure 1. Format of the programs}

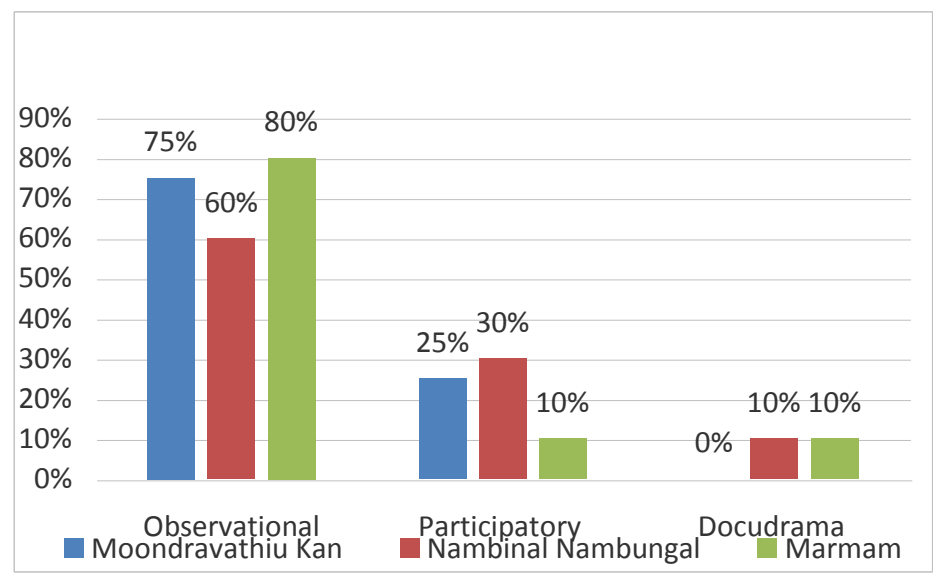

The 40 episodes of overall Non-Fiction programs were analyzed in one-month period. All the three programs had mostly used observational documentary format which is the highest 
percentage with $72 \%$ in average. The docudrama is the least followed format which is $10 \%$, while the participatory documentary style is followed in an average of $22 \%$.

\subsubsection{Content Types of the Programs}

The content of the analyzed programs was mostly related to traditional religious beliefs, precognition, blind beliefs (such as self-hurting, magic healing) and paranormal beliefs. It is clear that the content of the program is mostly related to religious beliefs with a highest average percentage of $38.3 \%$, followed by blind beliefs, paranormal beliefs, and precognition with the average of $35 \%, 15 \%$, and $11.6 \%$ respectively.

Figure 2. Content Types of superstitions shown in programs

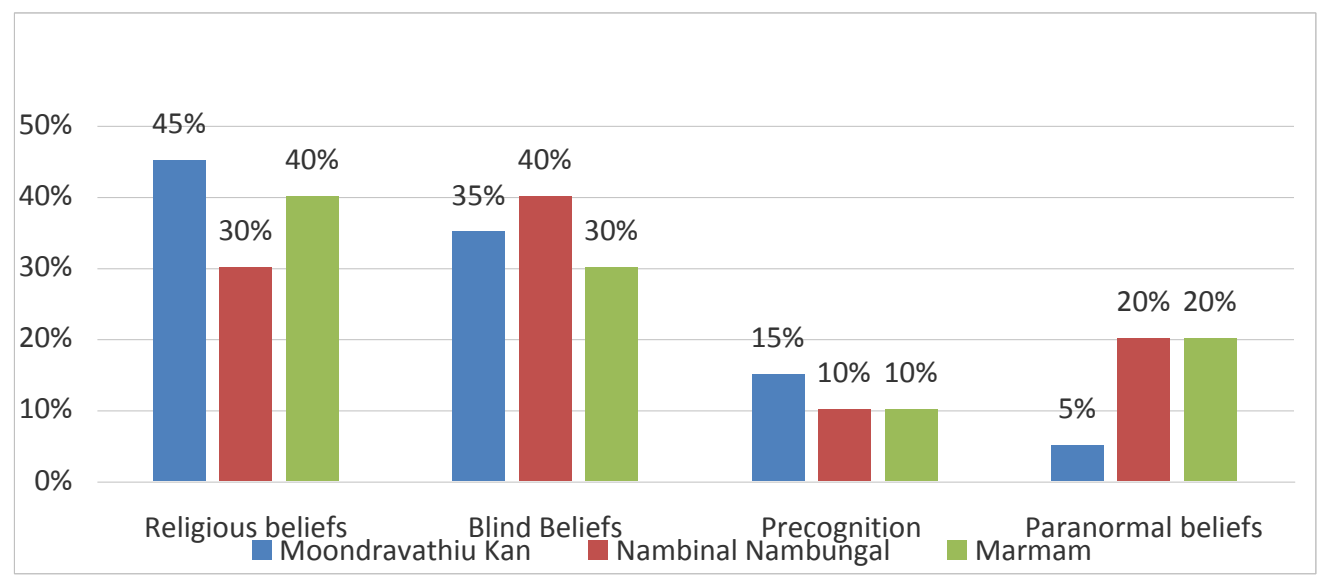

\subsubsection{Narration Style}

Narration plays an important role in Non-Fiction programs; it gives the people the sense of what is discussed in the visuals. The narration style followed is either anchor based (the anchor narrates the incident in a lively action) or voice-over based (recorded voice narrates the visuals to the audience) or a combination of both. Moondravathu Kan mostly made use of anchor based narration whereas Marmam mostly used voice-overs for narration. Nambinal Nambungal made equal use of both the styles.

\subsubsection{Tone of Narration}

The tone of narration reflects the seriousness of the story and narrators perception about the lively actions. Thus the tone of narration has great influence on the listeners, which means it indirectly draws conclusions in the mind of listeners in favor of the action shown or against it making them to believe or to criticize. So, to be on safer side, these programs mostly follow the neutral tone of narration, leaving the conclusions in the hands of the audience. The data reveals that the tone of the narration is $15 \%$ supportive, $20 \%$ criticizing and $65 \%$ neutral. 
Table 2. Narration Followed in the Non-Fiction programs

\begin{tabular}{|l|c|c|c|}
\hline $\begin{array}{l}\text { Tone of the narration and } \\
\text { conclusions drawn }\end{array}$ & Moondravathu Kan & $\begin{array}{c}\text { Nambinal } \\
\text { Nambungal }\end{array}$ & Marmam \\
\hline Supportive & $25 \%$ & $10 \%$ & $10 \%$ \\
\hline Criticism & $10 \%$ & $20 \%$ & $30 \%$ \\
\hline Neutral & $65 \%$ & $70 \%$ & $60 \%$ \\
\hline
\end{tabular}

\subsubsection{Interview Component with Stakeholders in the Programs}

The interview of persons who are associated with the story adds advantage to the program. By this way, the programs try to add credibility to the content. The interview of experts gives a better idea about the content supporting or clashing against it. Interview of experts reveals the scientific reason behind the superstitions and help in better understanding and eradicating blind beliefs among the audience, but the programs like Moondravathu Kan and Nambinal Nambungal have very less number of expert interviews which means it covers only the believers of the issue. Out of three categories, the interview of victims/witness is the highest with $68.3 \%$ in average of overall three programs and it is followed by other two categories with $18.3 \%$ and $13.3 \%$ in average.

Table 3. Interview Component with Stakeholders in the Programs

\begin{tabular}{|l|c|c|c|}
\hline \multicolumn{1}{|c|}{ Elements } & Moondravathu Kan & Nambinal Nambungal & Marmam \\
\hline $\begin{array}{l}\text { Interview with } \\
\text { victims/witness }\end{array}$ & $65 \%$ & $90 \%$ & $50 \%$ \\
\hline Interview with experts & $5 \%$ & $0 \%$ & $50 \%$ \\
\hline No interviews & $30 \%$ & $10 \%$ & $0 \%$ \\
\hline
\end{tabular}

\subsubsection{Appeal of the Programs}

The appeal is the emotional response that program creates in the audience. The emotional response varies based on the content of the program. The program propagates in a way that it occupies the audience with a thrilling feel and sometimes it also gives horror feel, especially when the content is based on paranormal activities. The program Moondravathu Kan creates a thrilling feel.

\subsubsection{Visual Effects/ Animation}

The programs make use of different kinds of visual elements to make the content more interesting and sensible. Few programs (Moondravathu Kan, Marmam) have used pictures to represent the history of the issue and $60 \%$ of the total episodes use visual elements like pictures, animations and video effects. Nambinal Nambungal has used only minimal (10\%) pictures and animation in total episodes analyzed during the research period.

\subsection{Results of the survey}

The researcher identified 132 audiences who watch Non-Fiction programs and survey was conducted among them. The responses are presented below: 


\subsubsection{Demographic Profile of Survey Participants}

The age span of respondents who watched the Non-Fiction programs was between 18 and 60. Most of the respondents belong to age span between 18 and 25 because like to watch NonFiction programs more. $26 \%$ of the respondents belong to age category $26-35$, and $21 \%$ of the respondents belong to age category 36-45. 19\% of the respondents were aged between 46 and 60 . Regarding the gender $52 \%$ of the respondents were males and $48 \%$ were females.

\section{Figure 3. Age group of the respondents}

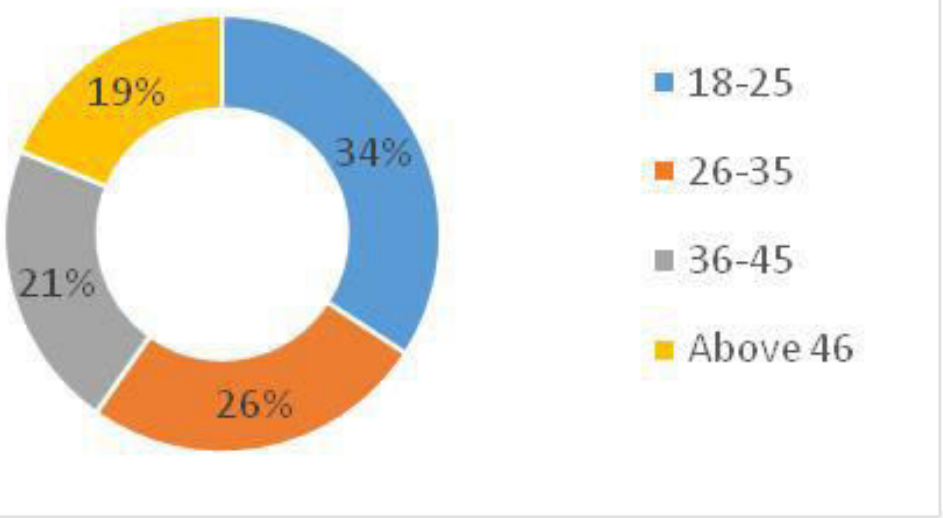

\subsubsection{Respondents' Favorite Program Category}

On television channels, many programs are telecasted. But, the audience is watching few programs, which are of interest. About $42 \%$ of the respondents liked to watch Non-Fiction programs because they find these programs very interesting. About $23 \%$ of the respondents liked to watch serials, and other $23 \%$ of the respondents liked to watch talk shows because these shows involve celebrities and/or discuss interesting topics.

Figure 4. Respondent's favorite program category

\begin{tabular}{|c|c|c|c|c|}
\hline $60.00 \%$ & & \multicolumn{3}{|c|}{$54 \%$} \\
\hline $50.00 \%$ & & & & \\
\hline & \multirow{2}{*}{$29 \%$} & \multirow{2}{*}{$30 \%$} & & \multirow[b]{3}{*}{$16 \%$} \\
\hline $30.00 \%$ & & & & \\
\hline $20.00 \%$ & & & & \\
\hline $10.00 \%$ & & & & \\
\hline \multirow[t]{2}{*}{$0.00 \%$} & & & & \\
\hline & Serials & Talk Shows & $\begin{array}{c}\text { Non-Fiction } \\
\text { programs }\end{array}$ & Other \\
\hline
\end{tabular}




\subsubsection{Respondents' Preferences on Non-Fiction Programs involving Superstitions}

Next to their favorite programs, the research asked another question on their preference on non-fiction programs involving superstitions. About $29 \%$ of the respondents watched Moondravathu Kan program because it explores a different story in each episode and it creates suspense among viewers thereby stimulating their curiosity. Fear Files stood next with $28 \%$ of the viewer's interest because this program depicts real-life stories with added fiction. Apart from this, $20 \%$ of the respondents watched Nambinal Nambungal, and $13 \%$ of respondents watched Marmam, because this program has less exposure than other programs.

\section{Figure 5. Respondents' preferences for Non-Fiction programs}

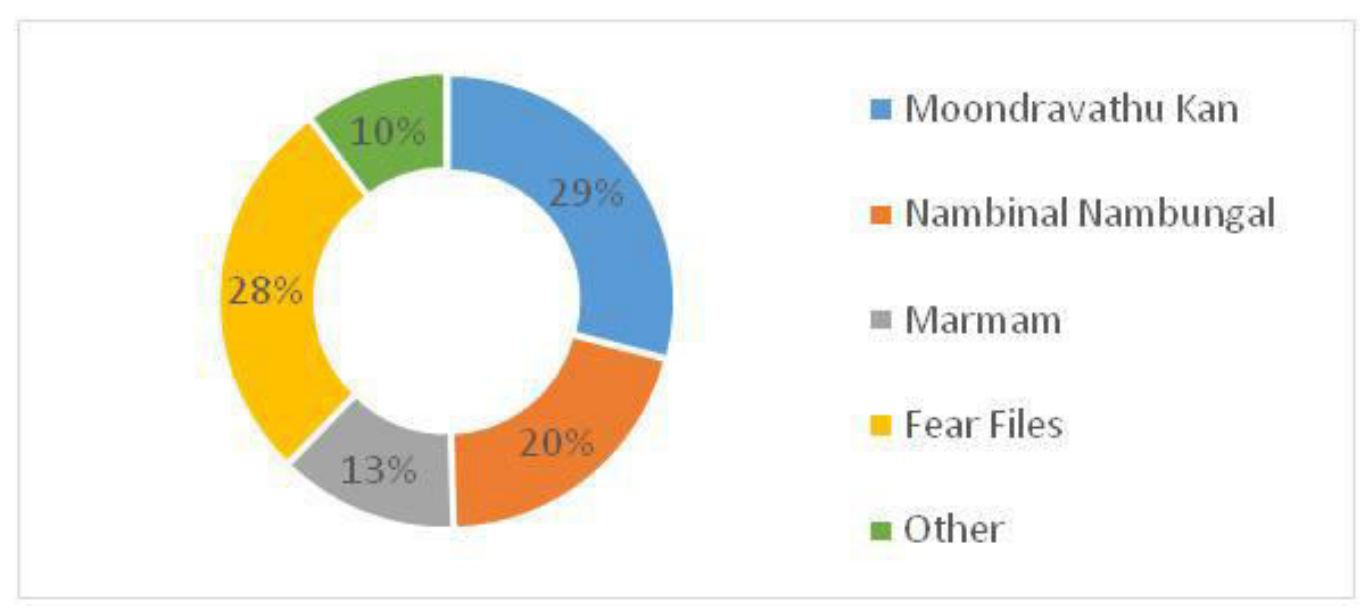

\subsubsection{Respondents' Frequency in Watching Non-Fiction programs}

Among the audience, $34 \%$ of the respondents watched these Non-Fiction programs regularly because they feel it is very interesting and they don't want miss an interesting episode and $43 \%$ of respondents watch these programs rarely because they only watched episodes that discussed their topic of interest and few others watched these programs only when they have got time to watch them because these programs were aired during prime time and on weekends, so there was a competition with other popular prime time programs.

Figure 6. Respondents' frequency in watching non-fiction programs

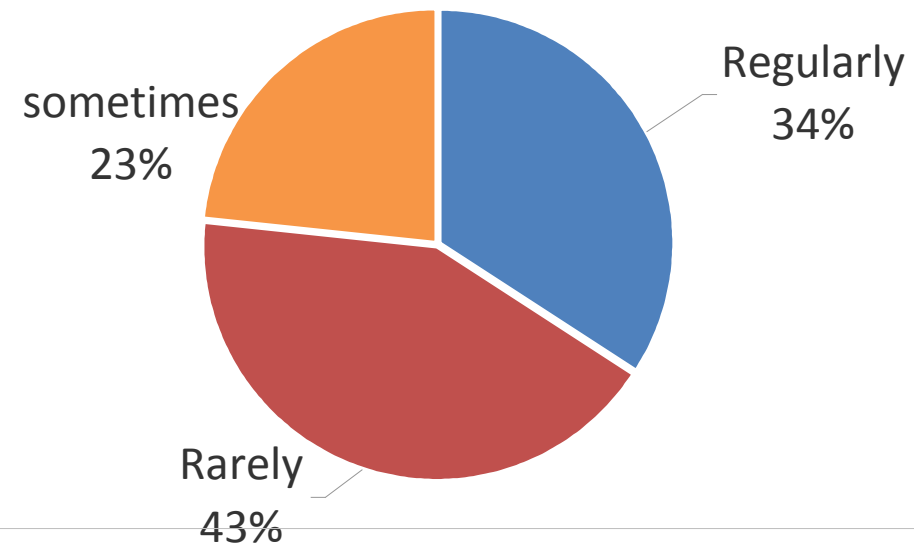




\subsubsection{Time Spent by the Respondents}

More than half $(51 \%)$ of the respondents spent more than 2 hours watching Non-Fiction television programs, while $34 \%$ of the respondents spend only an hour watching Non-Fiction programs. Apart from this, $15 \%$ of respondents watch Non-Fiction programs less an hour because they watch them just for entertainment.

\subsubsection{Respondents' Beliefs in Superstitions}

The respondents who believe the superstitions and those who don't are in equal percentage. The reason why respondents believe in superstitions is because of their parents influence and in few cases they believe because of their personal experience related to superstitions. The reason why $50 \%$ of respondents didn't believe in superstitions is because they were well educated and they felt that few superstitions are rumours that were spread by few people for their own benefits.

\subsubsection{Respondents' Belief in different types of Superstitions}

Respondents were holding beliefs in various superstitions. Among the respondents $47 \%$ believed in astrology and 30\% of the respondents believde in paranormal beliefs due to personal experiences regarding such beliefs. $22 \%$ of respondents believed that black magic is real, and $14 \%$ believed in magic healing.

Figure 7. Respondents' belief in different type of superstitions

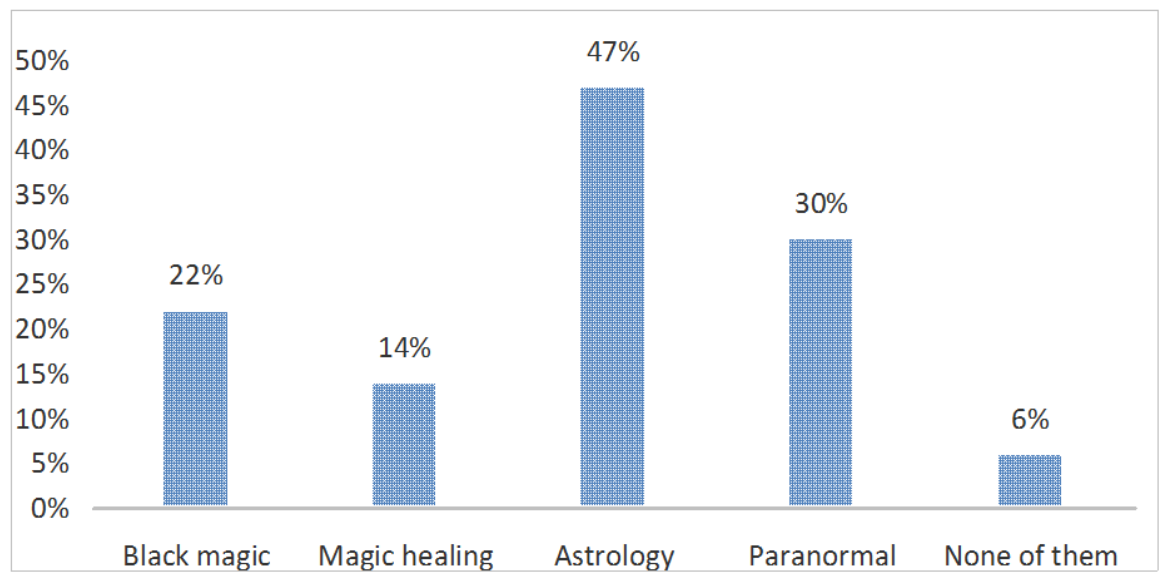

\subsubsection{Respondents' sources of Knowledge about Superstitions}

The respondents have knowledge about superstitions from various sources. Most of the respondents (50\%) learn superstitions from the Television, $28 \%$ of the respondents learn superstitions from society/friends, while $16 \%$ of the respondents learn superstitions from their parents and only $6 \%$ of the people learned superstitions from their personal experiences. 
Figure 8. Respondent's source of knowledge about superstitions

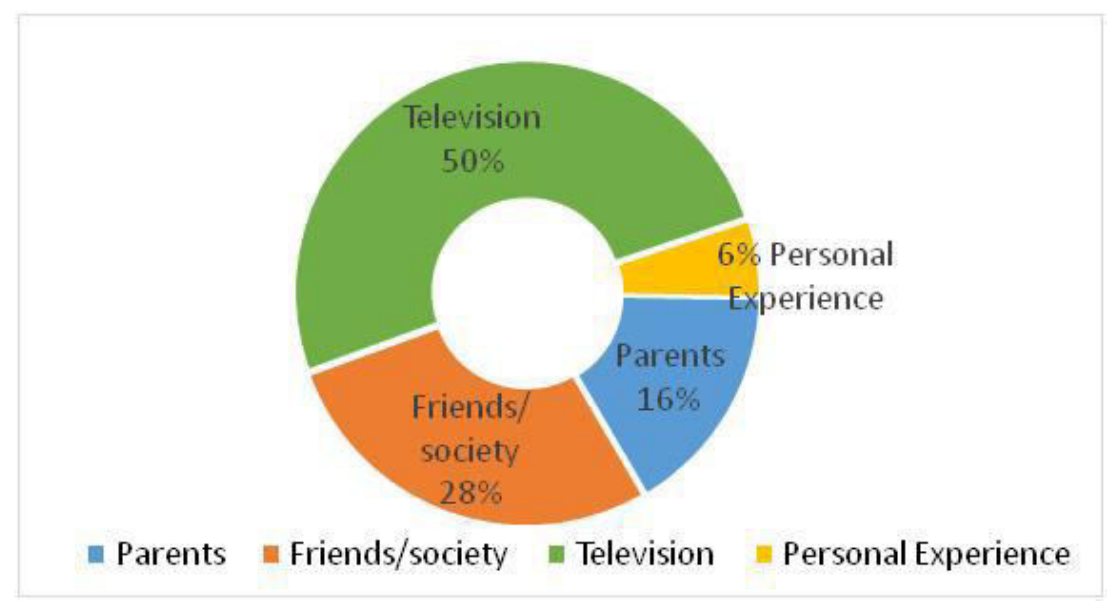

\subsubsection{Respondents' personal experiences about superstitions in real life}

The majority of the respondents (78\%) didn't encounter personally any superstitions that they saw in Non-Fiction television programs, whereas $22 \%$ of the respondents have encountered in real life, superstitions which they watched on television.

\subsubsection{Respondents' opinions about non-fiction programs involving superstitions}

The majority of the respondents (47\%) only partially believed that the stories shown in NonFiction programs were true. Only about $26 \%$ of respondents believed that the stories shown in NonFiction Television programs were absolutely true, while $27 \%$ of the respondents did believe that the stories were absolutely not true.

\subsubsection{Superstition practices suggested to friends by the respondents}

$72 \%$ of the respondents neither supported nor suggested the superstitions to others which they learned from television program, $15 \%$ of the respondents have not practiced but suggested few superstitions-related practices to others, whereas $7 \%$ of the respondents have practiced but not suggested superstitions-related practices to others. Only 6\% of the respondents had practiced and also suggested others to practice superstition which they saw in Non-Fiction Television programs.

Figure 9. Respondents who have practiced or suggested superstitions

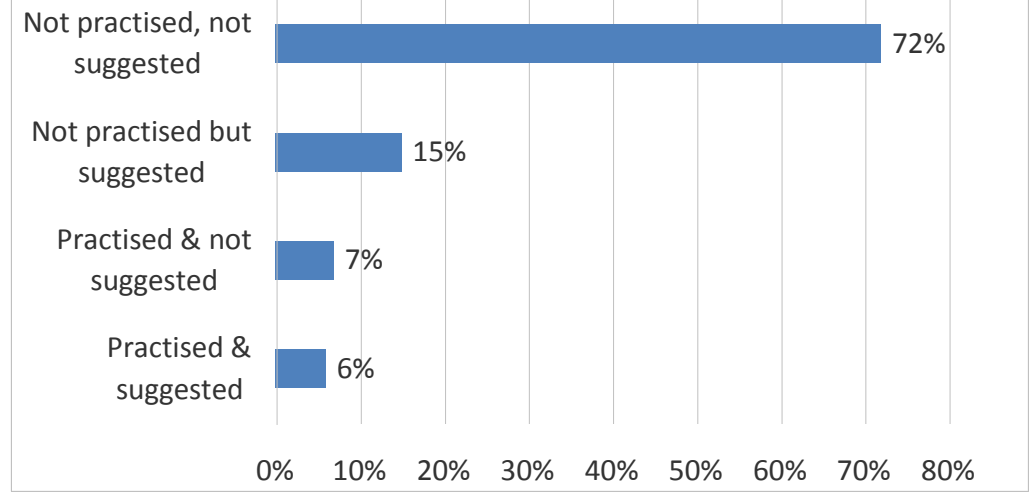




\subsubsection{Respondents' emotions while watching Non-Fiction Programs}

One-fourth of the respondents $(25 \%)$ felt amused while watching Non-Fiction television program, $21 \%$ of the respondents felt indifferent while watching programs that showed content related to superstition, $18 \%$ of the respondents felt excited while watching these programs and $14 \%$ of the respondents felt angry while they watched Non-Fiction Television programs.

\section{Figure 10. Respondents’ emotions while watching Non-Fiction Programs}

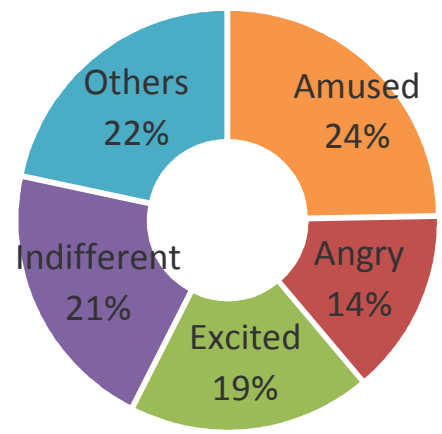

\subsubsection{Influence of Non-Fiction program on the Level of Belief among the Respondents}

About half (48\%) of the respondents said watching Non-Fiction programs did not have any effect on their existing beliefs while $30 \%$ of the respondents feel that watching these programs have stimulated their interest in superstitions. Apart from this, $18 \%$ of the respondents felt that watching Non-fiction shows had strengthened their belief in superstitions.

Figure 11. Influence of non-fiction program on the Level of Belief among the Respondents

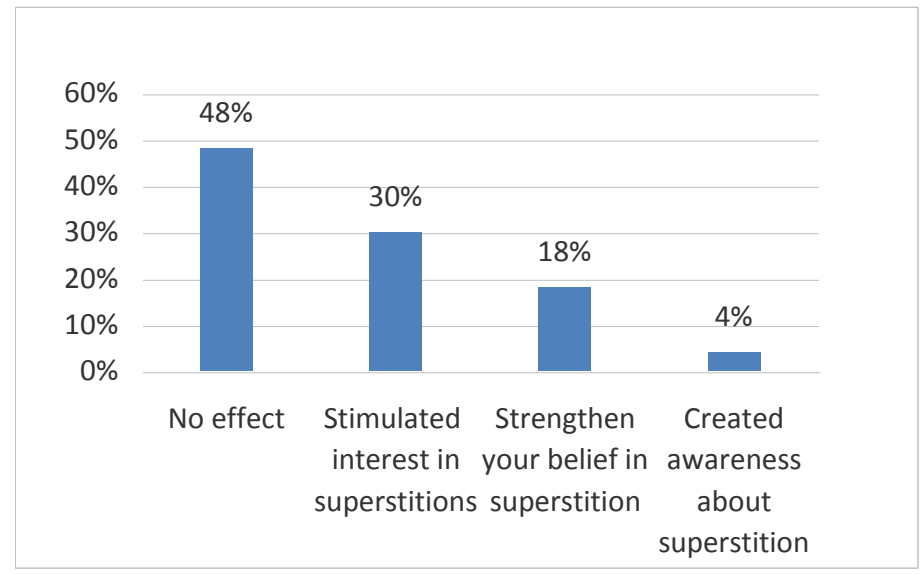

\subsubsection{Respondents' Opinions on Telecasting Content Related to Superstition}

The respondents were asked whether it is right to broadcast content related to superstition in television programs. Their answers were: $60 \%$ of the respondents felt it was right to telecast content related to superstition in television programs because there are people who just watch these programs for entertainment and others who believe in superstition and like to know more about 
them, whereas $40 \%$ of the respondents say that it is not right to telecast content related to superstitions because they don't believe in superstitions and telecasting such content can be harmful to people.

\section{Discussions}

Most of the superstition programs were being telecasted in the prime time especially on weekends. The majority of the content was related to religious beliefs and blind beliefs like magic healing, future prediction, and black magic. These programs gather information from practitioners or public and analyze the details and telecast them in a dramatized format. Almost $65 \%$ of the episodes used a neutral tone of narration and drew no judgment about the fact. About $50 \%$ of the respondents believed in superstitions and 50\% didn't. About 34\% of respondents watched Non-Fiction programs regularly. The majority $(50 \%)$ of the respondent said that they came to know about superstitions from the television. About $27 \%$ of respondents had followed practices related to superstitions after watching them on television programs. A majority of $47 \%$ of the respondents believes that the stories shown in Non-Fiction programs were partially true. Among the respondents, $48 \%$ of them said that they felt no effect from watching Non-Fiction programs, while $30 \%$ of respondents felt that it stimulated their interest towards superstitions. $60 \%$ of the respondents said it is right to broadcast programs about superstition on television channels for entertainment purposes, while $40 \%$ of respondents opposed this view and said these created bad social influence. Most respondents believed in astrology, whereas least number of respondents believed in magic healing.

\section{Conclusion}

From this study, it is evident that $50 \%$ of the people still believe in superstitions. Since, people believe that the majority of the stories in Non-Fiction programs are only partially true, these don't have much effect of program on them. But watching these programs have reinforced superstitious beliefs in few people and also stimulated interest towards superstitions in few others. The non-believers don't care about watching content related to superstition because it is just an entertainment to them, while the believers want these programs to broadcast such content because they are interested in it and they embrace it. Another important fact to be noted is that this study revealed that television, despite raising awareness, has enhanced superstition in the majority of people. Television channels and program producers should avoid telecasting content that would reinforce superstitious beliefs in the audience. Television programs should include, as much as possible, expert opinions about the topics - which may provide deeper understanding of the events along with scientific explanations on matter. Television programs should make some effort to clarify the tricks behind the superstitions rather than just simply stating the facts. This way, awareness can be raised in society.

\section{References}

1. Balderston, John L. in the play Dracula (1927), spoken by the character Von Helsing. In the script Dracula: the Vampire Play in Three Acts (Samuel French Inc., 1960), 25. Available at: http://quotes.yourdictionary.com/author/quote/547782\#oWyYiPL3gD7DJb0E.99. [Accessed 27 June 2017]

2. Boshier, R., 1973. An Empirical Investigation of the Relationship between Conservatism and Superstition. British Journal of Social and Clinical Psychology, 12, pp.262-267. 
3. Blackmore, S.J., 1994. Are women more sheepish? Gender differences in belief in the paranormal. In: Women and parapsychology (International conference), Dublin, 1991. New York: Parapsychology Foundation.

4. Cantor, J., Zillmann, D., and Bryant, J., 1994. Confronting children's fright responses to mass media. In: D. Zillmann, J. Bryant and A.C. Huston, eds. Media, children, and the family: Social scientific, psychodynamic, and clinical perspectives. Hillsdale, N.J: Erlbaum. pp.139-50.

5. Clarke, D., 1991. Belief in the paranormal: A New Zealand survey. Journal of the Society for Psychical Research, 57(823), pp.412-425.

6. Corsini, R.J., 2002. Dictionary of psychology. Philidelphia, PA: Brunner/Mazel.

7. Emme, E.E., 1940. Modification and origin of certain beliefs in superstition among 96 college students. Journal of Psychology, 10(2), pp.279-291.

8. Emmons, C.F. and Sobal, J., 1981. Paranormal beliefs: Testing the marginality hypothesis. Sociological Focus, 14(1), pp.49-56.

9. Feder, K.L., 1984. Irrationality and popular archaeology. American Antiquity, 49(3), pp.525-541.

10. Gerbner, G., Gross, L., Morgan, M., Signorielli, N., and Shanahan, J., 2002. Growing up with television: Cultivation processes. In: J. Bryant and D. Zillmann, eds., LEA's communication series. Media effects: Advances in theory and research. Mahwah, NJ, US: Lawrence Erlbaum Associates Publishers. pp.43-67.

11. Irwin, H.J., 1993. Belief in the Paranormal: A Review of the Empirical Literature. Journal of the American Society for Psychical Research, 87(1), pp.1-39.

12. Khantipalo, Bhikkhu, ed., 2013. Life's Highest Blessings: The Maha Mangala Sutta. Translation and commentary by R.L. Soni. Sri Lanka: Buddhist Publication Society.

13. Kurtz, P., 1985. The responsibilities of the media and paranormal claims. Skeptical Inquirer, 9(4), pp.357-62.

14. Lester, D., Thinschmidt, J.S., and Trautman, L.A., 1987. Paranormal belief and Jungian dimensions of personality. Psychological Reports, 61(1), p.182. Available at: http://journals.sagepub.com/doi/pdf/10.2466/pr0.1987.61.1.182 [Accessed 26 June 2017]

15. Lippmann, W., 1922. Public Opinion. Ch.1.: The world outside and the pictures in our heads. New York: MacMillan Co.

16. Lundeen, G.E. and Caldwell, O.W., 1930. A study of unfounded beliefs among school seniors and college students. Journal of Educational Research, 22, pp.257-273.

17. Maione, I., 1998. Testing Put to the Test. Skeptical Inquirer, 22(3), pp.21-22.

18. McGarry, J.J., and Newberry, B.H., 1981. Beliefs in paranormal phenomena and locus of control: A field study. Journal of Personality and Social Psychology, 41(4), 725-736.

19. Morris, B., 2013. Quotes we cherish. Quotations from Fausto Cercignani, eBook. p. 39. Available at: http://www.lulu.com/shop/brian-morris/quotes-we-cherish-quotations-from-faustocercignani/ebook/product-22207290.html [Accessed 28 June 2017]

20. Ofori, P.K., Tod, D., and Lavallee, D., 2016. An exploratory investigation of superstitious behaviours, coping, control strategies, and personal control in Ghanaian and British studentathletes. International Journal of Sport and Exercise Psychology, pp.3-19.

21. Risen, J.L. and Nussbaum, D., 2013. Sense and Superstition. New York Times. SR 12, 4 October. Available at: https://www.nytimes.com/2013/10/06/opinion/sunday/sense-and-superstition.html [Accessed 26 June 2017]

22. Sparks, G.G., Spirek, M.M., and Hodgson, K., 1993. Individual differences in arousability: Implications for understanding immediate and lingering emotional reactions to frightening mass media. Communication Quarterly, 41(4), pp.465-476. 
23. Tobacyk, J.J., Nagot, E., and Miller, M., 1988. Paranormal beliefs and locus of control: A multidimensional examination. Journal of personality assessment, 52(2), pp.241-246.

24. Wiseman, R. and Watt, C., 2004. Measuring superstitious belief: Why lucky charms matter. Personality and Individual Differences, 37(8), pp.1533-1541.

25. Wuthnow, R., 1976. Astrology and marginality. Journal for the Scientific Study of Religion, 15(2), pp.157-168.

26. *** Maharashtra Prevention and Eradication of Human Sacrifice and other Inhuman, Evil and Aghori Practices and Black Magic Act, 2013. Nagpur: Maharashtra Legislative Assembly. 